\title{
What are physical education teachers being told about how to teach sport? An exploratory analysis of sport teaching in physical education
}

\begin{tabular}{c|c} 
Rick Baldock & Shane Pill \\
$\begin{array}{c}\text { Australian Council for Health, Physical } \\
\text { Education and Recreation (SA Branch) } \\
\text { rick@achpersa.com.au }\end{array}$ & Flinders University \\
\hline
\end{tabular}

Keywords: sport, teaching, physical education, pedagogy, models

\begin{abstract}
This literature review investigated current and emerging pedagogical directions indicated to physical education (PE) teachers in the research literature. The search strategy used the Google Scholar database to initiate the scan, and then extended into other databases as well as the reference lists of published papers to locate relevant studies. Criteria for inclusion of papers for this review included: 1. Published in English between 2000 to December 2015; 2. Original research published in either peer reviewed journals or text books; 3 . Addresses the delivery of sport and PE within both Australian and international school aged children and young people; 4. Papers or book chapters that addressed theoretical underpinnings and concepts of delivering sport and PE. The search identified 57 papers or chapters for inclusion. The major findings of the analysis were: 1. Game Based approaches (such as Game Sense (Australia), TGfU (United Kingdom) and Tactical Games (North America) to learning in PE technical and tactical dimensions of skilled performance in game play are promoted; 2 . The Sport Education curriculum and instruction model is well researched and validated as a design to provide authentic, educationally rich sport experiences for students in the context of school PE; and 3. Personal and social development is an often-cited outcome of quality PE teaching in schools. Researchers have supported the use of a "tool kit" of instructional strategies to achieve student learning outcomes in PE (Pill, 2011).
\end{abstract}

\section{Introduction}

We acknowledge the place of sport in physical education (PE) is contested, and it is not universally agreed that sport in PE is good for, or engages, all children. However, sport has also been described as 'pivotal' (Green, 2000) and integral (Bailey \& Kirk, 2009) to PE. Laker (2002) argues that in broad terms "sport, in the educational guises of PE and school sport, has a major role to play in the education of young people" (p. 6), legitimating the existence of PE in schools (Laker, 2003). Kirk (2006) also makes a strong case for the inclusion of sport in school PE as play, games and sports at their best are conceived as intrinsically good things, among the most important and serious of human activities and hence they are an important part of the school curriculum. Internationally, games and sport are recognised as one of the most important elements of the PE curriculum, representing the "prime source of content and key contexts for teaching and learning" (Lopez, Jordan, Penney \& Chandler, 2009, p. 47). Recently, Drummond \& Pill (2011) argued for a curriculum vision for sport in PE that moves 
class participation beyond narrow technical and elite perspectives of sport participation to one which is more inclusive and understanding of broader sociological issues. They view sport in Australia as a significant cultural practice which demands a place within the PE curriculum. The authors agree with Brooker and MacDonald (1993) that sport within PE should assist PE as an educational process in order to promote, engage and facilitate sport participation within school, and beyond.

Remaining true to Arnold's (1979) definition of learning in PE and the Arnoldian conceptualisation of PE influencing Australian (Australian Council for Health, Physical Education and Recreation, 2008) and international (Brown \& Penney, 2012; Kirk, 1988) theorising and developments relating to the form and content of PE curricula, Drummond and Pill (2011) suggest that sport teaching and learning in PE is considered a context for:

- Learning in sport - this includes sport skill acquisition;

- Learning about sport - recognising that sport is structured in certain ways to bring about particular outcomes; and

- Learning through sport - understanding the embodied experience of sport to learn about a range of matters.

Pill (2008) frames these three dimensions as sport literacy. He suggests that sport literacy is potentially both a praxis and curriculum scaffold for sport curriculum design and enactment. He makes this claim because it expands the construction of 'ability' in PE typically viewed in $P E$ as a singular capacity centred on technical constructions of motor development. It does this by framing sport using the three types of movement learning that Arnold (1979) indicated as forming the distinctiveness of PE.

Confronting the norms of the traditional PE method that still remains the status quo in many school PE settings will play a pivotal role in educating through sport in areas of personal and social skill development, physical activity and participation, and the health of individuals and communities (Pill, 2015). We agree with Gimenez, Valenzuela and Casey (2010) that if teachers are being asked to change their practices then this should be informed by research evidence of comparative studies so that they can diversify their practice with understanding.

This literature review investigated current and emerging pedagogical directions indicated to PE teachers in the research literature. For many years, literature has supported the use of a "tool kit" of instructional strategies to achieve student learning outcomes in PE (Pill, 2011). For example, Mosston's Spectrum of Teaching Approaches (Mosston, 1966; Mosston \& Ashworth, 2008 ) is an example of one of these enduring ideas. More recently, however, scholarly and research literature has been promoting models based practice (MBP), particularly as a means for implementing student-centred approaches to learning (Casey, 2014; Hastie \& Casey, 2014). Metzler (2011) describes pedagogical models as blueprints for PE teaching, learning and assessment where each model has distinctive teaching and learning objectives. Casey (2014) suggested that while MBP has begun to help PE teachers to change and develop their pedagogies and curriculum we still do not fully understand the impact of changing to a MBP. Furthermore, advocates of MBP practice need to explore the pedagogical and curricular ramifications on teachers of the long-term adoption of a MBP. However, not all scholars are in agreeance with the concept and associated calls for fidelity to models by MBP advocates, with some arguing PE teachers are pragmatic interpreters of theory. Therefore, calls for model fidelity are inherently flawed (Stolz \& Pill, 2014).

As this report is detailing the current and emerging effective pedagogical practices that PE teachers and student teachers are learning and practicing it is useful to define the scope of the term 'pedagogy'. Tinning (2008) notes that the term, 'pedagogy' has widespread use in 
the fields of PE and sports coaching and is now established as an academic sub-discipline. While the term pedagogy has seen increased use in the English-speaking world the increased usage has not led to a coherent or shared understanding of what the term means. Tinning (2008) therefore argues for a notion of pedagogy that is generative in enabling teachers to think about the process of knowledge (re)production across the many sub-disciplines of kinesiology, including, but not limited to, sport pedagogy. It is this broader view of pedagogy that this literature review will use.

\section{Method}

Adopting similar methodology to Wallhead and O'Sullivan (2005) and Stolz and Pill (2014) to search the electronic database a combination of 'keywords' and 'search terms' were used. The initial search began using Google Scholar. These 'key words' and 'search terms' had been formulated by the authors of this literature review as we considered they directly addressed the topic under consideration - sport teaching in PE. The 'keywords' and 'search terms' used are summarised in Table 1.

Table 1. Search terms for the literature review

Sport pedagogy in physical education

Sport teaching in physical education

Skill acquisition in physical education

Game performance assessment

Authentic assessment sport

Authentic assessment sport in physical education

Skill teaching in physical education

Motor learning and physical education

Fundamental sport skills and physical education

Physical education pedagogy

Contemporary developments in game teaching and

Cooperative learning model in physical education

The criteria for inclusion of papers for this review were:

- $\quad$ Contemporary: Published in English between 2000 to 2015;

- $\quad$ Original: Research published in either peer reviewed journals or edited text books; and

- Research addresses the pedagogical delivery of sport and PE.

The exclusion criteria consisted of; 1 . Research on sport programs rather than the pedagogy or curriculum approach of delivery; 2 . Papers that compare pedagogical approaches across countries, and 3 . Papers essentially repeating the findings already published. Where possible, existing research summaries and systematic reviews were used in order to manage most effectively the large body of literature pertaining to sport teaching in PE. The literature used in the following comparative analysis is summarised in Tables 2-4. 


\section{Results and discussion}

The exploratory analysis of the literature presented in Tables 2-4 revealed three categories of publication. The first category of publication consisted of game-based models for sport and sport related games teaching (Table 2) focussed on the intent to teach game competency. The publications explored the tenets of the model or compared a game-based model to a more 'traditional' PE Method (Metzler, 2011), which Kirk (2010) has described as sport taught as sport techniques. Game based models use a classification system of games composing four categories based on common tactical elements called principles of play (Hopper \& Bell, 2001). This is why Metzler (2011) called game-based models 'tactical' models in his MBP framework. Since 2010 the following pedagogical approaches have been identified with game centred or game based approaches: Teaching Games for Understanding (TGfU), Play Practice, Game Sense, Tactical Games approach, Games Concept approach, Tactical Games Model, Tactical Decision Learning model, Ball Schulle and Invasion Games Competence model. (Teaching Games for Understanding (TGfU) Special Interest Group, 2016). This category of publications also considered assessment of sport in PE. The literature is suggesting game performance assessment procedures for 'authentic' assessment of ability or competency. Richard, Godbout \& Grèhaigne (2000), Pill (2008), Roberts and Fairclough (2012) and Mitchell, Oslin and Griffin (2013) have explained that valid tools are available for the assessment of students' participation in sport related games. Literature suggests students from Grade 5 are capable of using game observation tools with a moderate to good level of precision and inter-observer reliability, and that as the grade level increases their assessments become more accurate and reliable (Richard et al, 2000).

While the literature is unclear to the technical skill acquisition advantages of game-based compared to a more traditional directive practice style the evidence suggests young people enjoy sport taught using a game-based model. Students are reported to be more highly likely to participate and remain participating in sport and physical activity across the life span when these approaches are used.

Table 2. Game-based models for sport and sport related games teaching

\begin{tabular}{|c|c|c|}
\hline Publication & Title & Findings \\
\hline $\begin{array}{l}\text { Richard, J. F., Godbout, } \\
\text { P., \& Grèhaigne, J. } \\
\text { F. (2000) Research } \\
\text { Quarterly for Exercise } \\
\text { and Sport, 71(1), 85-91. }\end{array}$ & $\begin{array}{l}\text { Students' precision } \\
\text { and interobserver } \\
\text { reliability of performance } \\
\text { assessment in team } \\
\text { sports }\end{array}$ & $\begin{array}{l}\text { Demonstrated that students at the Grade } \\
5-8 \text { levels are capable of using the Team } \\
\text { Sport Assessment Procedure (TSAP) with } \\
\text { a moderate to good level of precision and } \\
\text { interobserver reliability, this being more so as } \\
\text { the grade level increases. }\end{array}$ \\
\hline $\begin{array}{l}\text { Mandigo, J. L., \& Holt, } \\
\text { N.L. (2000). Physical } \\
\text { and Health Education } \\
\text { Journal, 66(3), 14-19. }\end{array}$ & $\begin{array}{l}\text { The inclusion of } \\
\text { optimal challenge in } \\
\text { teaching games for } \\
\text { understanding }\end{array}$ & $\begin{array}{l}\text { The construct of optimal challenge is } \\
\text { introduced utilising the TGFU framework. }\end{array}$ \\
\hline $\begin{array}{l}\text { Hopper, T., \& Bell, R. } \\
\text { (2001). CAHPERD, 66(4), } \\
\text { 14-19. }\end{array}$ & $\begin{array}{l}\text { Games classification } \\
\text { system: Teaching } \\
\text { strategic understanding } \\
\text { and tactical awareness }\end{array}$ & $\begin{array}{l}\text { The Tactical Awareness Components to } \\
\text { Increase Cognition (T.A.C.T.I.C.) framework } \\
\text { with the principles of play for games offers } \\
\text { a systematic way to teach the tactical } \\
\text { complexity of games in the net/wall, territory, } \\
\text { target and batting/fielding game categories. }\end{array}$ \\
\hline
\end{tabular}




\begin{tabular}{|c|c|c|}
\hline Publication & Title & Findings \\
\hline $\begin{array}{l}\text { Austin, B., Haynes, } \\
\text { J., \& Miller. J. (2004). } \\
\text { Paper Presented at the } \\
\text { Australian Association } \\
\text { for Research in } \\
\text { Education Conference } \\
\text { Melbourne, Victoria. } \\
\text { December, } 2004 .\end{array}$ & $\begin{array}{l}\text { Using a game sense } \\
\text { approach for improving } \\
\text { fundamental movement } \\
\text { skills }\end{array}$ & $\begin{array}{l}\text { Post-test results showed overall improvements } \\
\text { in the level of mastery performance of the kick. } \\
\text { Implications of this research include the } \\
\text { teaching strategies employed to increase } \\
\text { fundamental motor skill proficiency. } \\
\text { High levels of motivation and interest in the PE } \\
\text { lessons were noted. } \\
\text { The authors also noted that "although the } \\
\text { techniques approach to skill development } \\
\text { may be more focused (and familiar) in terms } \\
\text { of students knowing what the teacher wants - } \\
\text { the sustained interest and cognitive stimulation } \\
\text { of the problem solving/Games sense approach } \\
\text { to learning has been highlighted in this project. }\end{array}$ \\
\hline $\begin{array}{l}\text { Kirk, D. (2006) Quest, } \\
58(2), 255-264 \text {, }\end{array}$ & $\begin{array}{l}\text { Sport Education, Critical } \\
\text { Pedagogy, and Learning } \\
\text { Theory: Toward an } \\
\text { Intrinsic Justification for } \\
\text { PE and Youth Sport }\end{array}$ & $\begin{array}{l}\text { School PE is well placed to take up the } \\
\text { challenge of sustaining sport as a moral } \\
\text { practice and that the pedagogical tools } \\
\text { already exist to do this in the form of a critical } \\
\text { pedagogy. }\end{array}$ \\
\hline $\begin{array}{l}\text { Chow, J. Y., Davids, K., } \\
\text { Button, C., Shuttleworth, } \\
\text { R., Renshaw, I. \& Araújo, } \\
\text { D. (2007). Review of } \\
\text { Educational Research. } \\
\text { 77(3), 251-278 }\end{array}$ & $\begin{array}{l}\text { The Role of Nonlinear } \\
\text { Pedagogy in Physical } \\
\text { Education }\end{array}$ & $\begin{array}{l}\text { Proposed using key conceptual components } \\
\text { from a dynamical systems perspective to } \\
\text { lay the foundations for the development of } \\
\text { a conceptual model for nonlinear pedagogy, } \\
\text { providing a theoretical framework to further } \\
\text { examine motor learning issues in pedagogy } \\
\text { and PE. }\end{array}$ \\
\hline $\begin{array}{l}\text { Pill, S. (2008). Paper } \\
\text { presented at the } \\
\text { Flinders University 'Play } \\
\text { to Educate' - Sport in } \\
\text { Education Conference, } \\
\text { January } 21^{\text {st }} 2008 \text {. }\end{array}$ & $\begin{array}{l}\text { Involving students in the } \\
\text { assessment of game } \\
\text { performance in physical } \\
\text { education. }\end{array}$ & $\begin{array}{l}\text { Authentic game and sport play assessment in } \\
\text { PE is viewed as the process of collecting data, } \\
\text { interpreting data, and using data to create } \\
\text { knowledge and further develop learning. } \\
\text { Procedures, such as the TSAP and Game } \\
\text { Performance Assessment Instrument (GPAI), } \\
\text { when embedded in the teaching-learning } \\
\text { process, do more than provide evidence for } \\
\text { summative assessment. The procedures } \\
\text { provide for both valid and reliable assessments } \\
\text { that continuously inform teaching and learning. } \\
\text { The GPAl and TSAP are examples of authentic } \\
\text { PE game assessment as they facilitate } \\
\text { learning as well as provide for the collection of } \\
\text { evidence of learning having occurred. }\end{array}$ \\
\hline $\begin{array}{l}\text { Farrow, D. \& Reid, } \\
\text { M. (2010). Journal of } \\
\text { Sports Sciences, 28(7), } \\
\text { 723-732 }\end{array}$ & $\begin{array}{l}\text { The effect of equipment } \\
\text { scaling on the skill } \\
\text { acquisition of beginning } \\
\text { tennis players }\end{array}$ & $\begin{array}{l}\text { The modified ball/scaled court intervention } \\
\text { group rated their experience significantly } \\
\text { happier than the standardised adult group. } \\
\text { There is a stronger learning effect generated } \\
\text { by court scaling relative to the influence of ball } \\
\text { type. }\end{array}$ \\
\hline
\end{tabular}




\begin{tabular}{|c|c|c|}
\hline Publication & Title & Findings \\
\hline $\begin{array}{l}\text { Pill, S. (2011) PHENex } \\
\text { Journal, 3(1) }\end{array}$ & $\begin{array}{l}\text { Seizing the moment: } \\
\text { Can game sense further } \\
\text { inform sport teaching } \\
\text { in Australian physical } \\
\text { education }\end{array}$ & $\begin{array}{l}\text { The National Curriculum is an opportunity } \\
\text { to shape sporting experiences as educative } \\
\text { through quality curriculum and teaching as } \\
\text { provided through a Game Sense approach. } \\
\text { The author notes that teachers across } \\
\text { Australia strive for deep learning through high } \\
\text { quality teaching-learning processes in all areas } \\
\text { of the curriculum. The case is made that Game } \\
\text { Sense can be the model to deliver this for the } \\
\text { sport component of the Australian Curriculum } \\
\text { for Health and PE. }\end{array}$ \\
\hline $\begin{array}{l}\text { Roberts, S. \& } \\
\text { Fairclough, S. (2012). } \\
\text { European Physical } \\
\text { Education Review, 18(1) } \\
\text { 97-113. }\end{array}$ & $\begin{array}{l}\text { A five-stage process } \\
\text { for the development } \\
\text { and validation of a } \\
\text { systematic observation } \\
\text { instrument: The system }\end{array}$ & $\begin{array}{l}\text { The SOTG-PE is a valid observation system for } \\
\text { recording activity, lesson context and teacher } \\
\text { interactions during various PE games lessons } \\
\text { from the invasion, net/wall and the striking and } \\
\text { fielding categories. }\end{array}$ \\
\hline
\end{tabular}

Harvey, S., \& Jarrett, K. (2013). Physical Education and Sport Pedagogy, 19:3, 278-300.

Light, R. (2013) Game Sense: pedagogy for performance, participation and enjoyment. Routledge.

Light, R., Curry, C., \& Mooney, A. (2014). Game Sense as a model for delivering quality teaching in physical education. Asia-Pacific Journal of Health, Sport and Physical Education, 5(1), 67-81.

Stolz, S. \& Pill S. (2014). European Physical Education Review. 20(1), 36-71. for observing the teaching of games in physical education (SOTG-PE)

A review of the gamecentred approaches to teaching and coaching literature since 2006

Ch2- The development of Game sense

Ch5 - Game Sense Pedagogy

Game Sense as a model for delivering quality teaching in physical education

Teaching games and sport for understanding:

Exploring and reconsidering its relevance in physical education
GCA pedagogies are of significant importance as they have the potential to promote change within current adult-centric cultures of youth sport and encourage engagement in physical activity over the life course. The authors recommend that GCA research undergo continued expansion.

Game based approaches to sports coaching and PE teaching have included:

- Teaching games for Understanding

- Game Sense (a less structured approach compared with TGfU)

To adopt this approach to teaching requires a significant change in pedagogy and the role of the teacher.

PE teachers using the Game Sense approach will be able to provide high-quality learning experiences for students and make a start toward making PE a valuable educational experience in schools.

If TGfU is to have improved relevance for teachers of PE more of an emphasis needs to be placed on the creation of standard characteristics of pedagogy that drive this practice within curricula. 


\begin{tabular}{|c|c|c|}
\hline Publication & Title & Findings \\
\hline $\begin{array}{l}\text { Drummond, M. \& Pill, } \\
\text { S. (2011). Ch } 11 \text { In } \\
\text { Georgakis, S. \& Russell, } \\
\text { K. (Eds.), Youth sport } \\
\text { in Australia, p165-178. } \\
\text { Sydney University Press }\end{array}$ & $\begin{array}{l}\text { The role of physical } \\
\text { education in promoting } \\
\text { sport participation in } \\
\text { school and beyond }\end{array}$ & $\begin{array}{l}\text { Argues for a curriculum vision for sport in PE } \\
\text { that moves class participation beyond narrow } \\
\text { technical and elite perspectives of sport } \\
\text { participation to one which is more inclusive } \\
\text { and understanding of broader sociological } \\
\text { issues. Proposes sport literacy for education } \\
\text { in, through and about sport. }\end{array}$ \\
\hline $\begin{array}{l}\text { Light, R. (2014). } \\
\text { Ch } 2 \text { p.29-39. In } \\
\text { Contemporary } \\
\text { developments in game } \\
\text { teaching. Routledge. }\end{array}$ & $\begin{array}{l}\text { Positive pedagogy for } \\
\text { physical education and } \\
\text { sport: Game Sense as } \\
\text { an example }\end{array}$ & $\begin{array}{l}\text { The positive nature of games based } \\
\text { approaches can support learning and make } \\
\text { it flourish. Through this approach, learning } \\
\text { to learn along with social learning make it } \\
\text { more likely that students will transfer their } \\
\text { understanding into other aspects of life. }\end{array}$ \\
\hline $\begin{array}{l}\text { Light, R. L. \& Harvey, S. } \\
\text { (2015). Sport, Education } \\
\text { and Society, Published } \\
\text { online } 04 \text { Mar } 2015\end{array}$ & $\begin{array}{l}\text { Positive Pedagogy for } \\
\text { sport coaching }\end{array}$ & $\begin{array}{l}\text { Using game-based models, like Teaching } \\
\text { Games for Understanding, Game Sense, Play } \\
\text { Practice and the Tactical-Decision Learning } \\
\text { Model makes it more likely to transfer } \\
\text { dialogue, reflection and purposeful social } \\
\text { interaction into life off the court or sports field } \\
\text { than models narrowly focussed on improving } \\
\text { sport technique and fitness. }\end{array}$ \\
\hline
\end{tabular}

The second category of publication dealt with the Sport Education (SE) model (Table 3). In Australia, SE originated in 1995 from a trial by Edith Cowan University's Sport and Physical Activity Research Centre (SPARC) and the Western Australian Ministries of Education, Sport and Recreation that was commissioned by the Australian Sports Commission's then AUSSIE SPORT National Unit. SE is a curriculum and instruction model designed to provide authentic, educationally rich sport experiences for students in the context of school PE (Siedentop, Hastie \& van der Mars, 2011). It has six basic features:

1. Seasons of sport;

2. Affiliation to a team;

3. Formal competition within the season;

4. Culminating events to conclude the season;

5. Record keeping to track achievement and enable recognition of team and individual accomplishments; and

6. Festivity to celebrate team and individual achievement.

Kirk (2004) noted that internationally public discussions about PE are often framed through approaches to elite sport or talent identification. He suggests that SE is one model that is a better alternative to the elite sport model 'talent identification'. He sees that SE enables the retention of sport in PE in a way that emphasises desirable ethical and educational outcomes. The model has been successfully applied beyond team games to athletics (Hastie, Calderon, Rolim \& Guarino, 2013).

Literature in this group also considered hybrids of SE with other models to enhance the micropedagogy of the SE model. For example, Alexander and Penney (2005) develop SE features within a game-based model to amplify the focus on game competency development. This led 
to a new relationship between SE and TGfU they called the 'Clinic-Game Day' model. Ennis (1999) described the Sport for Peace approach entwined with the SE model structures that included additional foci of:

- Conflict negotiation

- Self and social responsibility; and

- Care and concern for others

Similarly, Hastie and Buchanan (2000) described the development of a hybrid modelEmpowering Sport, which combined some distinguished features of SE (e.g. formal competition and the persisting team) together with facilitating personal responsibility from Teaching Personal and Social; Responsibility through Physical Activity (TPSR) to present a model of game play which demonstrated a particularly constructivist learning style. They found that some of the features of TPSR strengthened the foundation of SE, but a hybrid model (Empowering Sport) needed to be developed. This hybrid model presented a powerful triangle of goals: sport skill competence, social responsibility, and personal empowerment. Despite the positive results stemming from hybrid models such as Empowering Sport, follow-up studies specifically using these developments have not occurred and the original SE model continues to occupy the majority of scholarly and research literature informing PE teachers intentions to educate in, through and about sport.

Table 3. Sport education in PE model

\begin{tabular}{|c|c|c|}
\hline Publication & Title & Findings \\
\hline $\begin{array}{l}\text { Hastie, P. A. \& } \\
\text { Buchanan, A. M. (2000). } \\
\text { Research Quarterly for } \\
\text { Exercise and Sport, } \\
71(1), 25-35\end{array}$ & $\begin{array}{l}\text { Teaching Responsibility } \\
\text { through sport education: } \\
\text { Prospects of a coalition }\end{array}$ & $\begin{array}{l}\text { Some of the features of TPSR strengthened } \\
\text { the foundation of SE, but due to the need } \\
\text { to introduce new tasks and problems for } \\
\text { students, a hybrid model (Empowering } \\
\text { Sport) was developed. This hybrid, with } \\
\text { a predominately ecological integration } \\
\text { perspective, presents a curriculum model } \\
\text { that allows for achievement within a powerful } \\
\text { triangle of goals-sport skill competence, social } \\
\text { responsibility, and personal empowerment. }\end{array}$ \\
\hline $\begin{array}{l}\text { Browne, T., Carlson, } \\
\text { T., \& Hastie, A. (2004). } \\
\text { European Physical } \\
\text { Education Review, 10(2), } \\
\text { 199-214. }\end{array}$ & $\begin{array}{l}\text { A comparison of rugby } \\
\text { seasons presented in } \\
\text { traditional and sport } \\
\text { education formats }\end{array}$ & $\begin{array}{l}\text { Students reported that they enjoyed the unit, } \\
\text { regardless of the teaching approach adopted } \\
\text { and they believed that they experienced } \\
\text { improvement in skills, especially those in SE. } \\
\text { Furthermore, no student expressed the belief } \\
\text { that the 'season' or unit was too long. } \\
\text { The students in SE reported that they enjoyed } \\
\text { the greater autonomy and organisation duties } \\
\text { within the SE model, but the students in the } \\
\text { Traditional Group felt that their group was not } \\
\text { capable of the autonomy given to SE. }\end{array}$ \\
\hline $\begin{array}{l}\text { Kirk, D. (2004). Physical } \\
\text { Education and Sport } \\
\text { Pedagogy, 9(2), } \\
\text { 185-195. }\end{array}$ & $\begin{array}{l}\text { Framing quality physical } \\
\text { education: the elite } \\
\text { sport model or sport } \\
\text { education? }\end{array}$ & $\begin{array}{l}\text { SE is one model that is a better alternative to } \\
\text { the elite sport model. SE enables the retention } \\
\text { of sport in PE in a way that emphasises } \\
\text { desirable ethical and educational outcomes. }\end{array}$ \\
\hline
\end{tabular}




\begin{tabular}{|c|c|c|}
\hline Publication & Title & Findings \\
\hline $\begin{array}{l}\text { Hastie, P. (2005). In } \\
\text { Critical Inquiry and } \\
\text { Problem Solving in } \\
\text { Physical Education. } \\
\text { Routledge. }\end{array}$ & $\begin{array}{l}\text { Ch } 5 \text { Problem-solving in } \\
\text { teaching sports }\end{array}$ & $\begin{array}{l}\text { SE fits within a contemporary constructivist } \\
\text { theory of learning. Learning in SE should } \\
\text { increase student's interest and personal } \\
\text { ownership of new knowledge and } \\
\text { responsibilities. SE also promotes critical } \\
\text { inquiry where they not only are required } \\
\text { to solve problems but also examine the } \\
\text { consequences of their decisions. SE is thus a } \\
\text { student centred model. }\end{array}$ \\
\hline $\begin{array}{l}\text { Parker, M. B. \& Matthew } \\
\text { Curtner-Smith, M. } \\
\text { (2005). Physical } \\
\text { Education and Sport } \\
\text { Pedagogy, 10(1), 1-18. }\end{array}$ & $\begin{array}{l}\text { Health-related fitness } \\
\text { in sport education and } \\
\text { multi-activity teaching }\end{array}$ & $\begin{array}{l}\text { Results indicated that pupils in the multi- } \\
\text { activity (MA) unit spent slightly more than the } \\
\text { recommended } 50 \% \text { of lesson time in moderate } \\
\text { to vigorous physical activity (MVPA) while the } \\
\text { pupils in the SE unit did not approach this } \\
\text { level. The authentic and 'situated' nature of SE } \\
\text { appears to lead to a trade-off situation. }\end{array}$ \\
\hline $\begin{array}{l}\text { Wallhead, T. \& } \\
\text { O'Sullivan, M. (2005). } \\
\text { Physical Education and } \\
\text { Sport Pedagogy, 10(2), } \\
\text { 181-210. }\end{array}$ & $\begin{array}{l}\text { Sport Education: } \\
\text { physical education for } \\
\text { the new millennium? }\end{array}$ & $\begin{array}{l}\text { SE research indicates the model has the } \\
\text { potential to promote more positive cultural } \\
\text { dimensions of sport and offer a challenge } \\
\text { to the exclusionary aspects of much of } \\
\text { institutionalised sport. }\end{array}$ \\
\hline $\begin{array}{l}\text { Alexander, K. \& Penney, } \\
\text { K. (2005). Physical } \\
\text { Education and Sport } \\
\text { Pedagogy, 10(3), } \\
\text { 287-301. }\end{array}$ & $\begin{array}{l}\text { Teaching under } \\
\text { the influence: } \\
\text { Feeding games for } \\
\text { understanding into } \\
\text { the sport education } \\
\text { development-refinement } \\
\text { cycle. }\end{array}$ & $\begin{array}{l}\text { A new relationship between SE and TGfU } \\
\text { within what was called the 'Clinic-Game Day' } \\
\text { (CGD) model. }\end{array}$ \\
\hline $\begin{array}{l}\text { Kirk, D. (2006). Quest, } \\
\text { 58(2), 255-264. }\end{array}$ & $\begin{array}{l}\text { Sport education, critical } \\
\text { pedagogy, and learning } \\
\text { theory: Toward an } \\
\text { Intrinsic justification for } \\
\text { physical education and } \\
\text { youth sport }\end{array}$ & $\begin{array}{l}\text { School PE is well placed to take up the } \\
\text { challenge of sustaining sport as a moral } \\
\text { practice and that the pedagogical tools } \\
\text { already exist to do this in the form of a critical } \\
\text { pedagogy. }\end{array}$ \\
\hline $\begin{array}{l}\text { Mohr, D. J., Townsend, } \\
\text { J. S \& Pritchard, T. } \\
\text { (2006). The Physical } \\
\text { Educator, 18-29. }\end{array}$ & $\begin{array}{l}\text { Rethinking middle } \\
\text { school physical } \\
\text { education: Combining } \\
\text { lifetime leisure activities } \\
\text { and sport education } \\
\text { to encourage physical } \\
\text { activity }\end{array}$ & $\begin{array}{l}\text { SE and Life-time Leisure Activity are proposed } \\
\text { as solutions to address the pedagogical } \\
\text { problem for middle school PE. Both require a } \\
\text { shift in thinking about what is taught (content) } \\
\text { and how content is taught (instructional } \\
\text { methods). }\end{array}$ \\
\hline $\begin{array}{l}\text { Brock, S. J. \& Hastie, } \\
\text { P.A. (2007). ACHPER } \\
\text { Healthy Lifestyles } \\
\text { Journal, 54(1), 11-15. }\end{array}$ & $\begin{array}{l}\text { Students' conceptions } \\
\text { of fair play in sport } \\
\text { education }\end{array}$ & $\begin{array}{l}\text { If students only perceive success as winning, } \\
\text { then teachers are simply perpetuating an elite } \\
\text { sports model, rather than the goals of fair play } \\
\text { and equitable participation as espoused for SE. }\end{array}$ \\
\hline
\end{tabular}




\begin{tabular}{|c|c|c|}
\hline Publication & Tit/e & Findings \\
\hline $\begin{array}{l}\text { Hastie, P., de Ojeda, D. } \\
\text { M., Caldero'n Luquin, A. } \\
\text { (2011). } \\
\text { Physical Education and } \\
\text { Sport Pedagogy, 6(2), } \\
\text { 103-132. }\end{array}$ & $\begin{array}{l}\text { The development of } \\
\text { skill and knowledge } \\
\text { during a sport education } \\
\text { season of track and field } \\
\text { athletics }\end{array}$ & $\begin{array}{l}\text { SE classes outperformed the traditional } \\
\text { classes in both technique and skill execution. } \\
\text { Only the SE group made significant } \\
\text { improvements in content knowledge. }\end{array}$ \\
\hline $\begin{array}{l}\text { Rui Araújo, R., Mesquita, } \\
\text { I. \& Hastie, P. A. (2014). } \\
\text { Journal of Sports } \\
\text { Science and Medicine, } \\
13,846-858 .\end{array}$ & $\begin{array}{l}\text { Review of the status of } \\
\text { learning in research on } \\
\text { sport education: Future } \\
\text { research and practice }\end{array}$ & $\begin{array}{l}\text { Consideration should also be given to the } \\
\text { use of hybrid SE in order to provide a more } \\
\text { complete understanding of the teaching and } \\
\text { learning process and its complexity. }\end{array}$ \\
\hline $\begin{array}{l}\text { Harvey, S., Kirk, D. \& } \\
\text { O'Donovan T. M. (2014). } \\
\text { Sport, Education and } \\
\text { Society, 19(1), 41-62. }\end{array}$ & $\begin{array}{l}\text { Sport education as a } \\
\text { pedagogical application } \\
\text { for ethical development } \\
\text { in physical education } \\
\text { and youth sport }\end{array}$ & $\begin{array}{l}\text { If sport is to provide young people with an } \\
\text { education in ethical conduct, it must be } \\
\text { designed explicitly and intentionally to do so. } \\
\text { Pedagogical elements for ethical development } \\
\text { are presented: (1) ethical contracts; (2) sports } \\
\text { panels; (3) modified games; and (4) awards } \\
\text { and rewards. }\end{array}$ \\
\hline
\end{tabular}

The third category of publication dealt with personal and social development in PE using sport as the context for this development. In this category there was some overlap with the SE literature. For example, Harvey, Kirk and O'Donovan (2014) explained that the SE model can be a context for character development if designed deliberately for this intention. They suggested that four pedagogical applications within SE be considered by PE teachers, youth sport practitioners and administrators to promote ethical development: 1 . ethical contracts; 2 . sports panels; 3. modified games; and 4. awards and rewards systems.

Personal and social development is an often-cited outcome of a quality PE program in schools (Kirk, 2010). With growing media attention on elite athletes and their behaviours and the media positioning childhood and youth in a polarised manner as being either dangerous or in danger (Prout \& Hallett, 2003) then school (and sporting clubs) are often required to respond in ways that are practical and appropriate. Curricula response in Australian schools inevitably view the Health and PE Learning Area as the place where these values, skills and abilities are best learnt (Ministerial Council on Education, Employment, Training and Youth Affairs, 2008). Other examples of sport-based programs for personal and social skill learning include the Sports United to Promote Education and Recreation program (Danish, 2002) and Hokowhitu Program (Heke, 2001).

Table 4. Sport as a tool for personal and social skill teaching and learning in PE

\begin{tabular}{|c|c|c|}
\hline Publication & Title & Findings \\
\hline $\begin{array}{l}\text { Theodoulides, A. \& } \\
\text { Armour, K.M. (2001). } \\
\text { European Physical } \\
\text { Education Review, (1), } \\
\text { 5-23. }\end{array}$ & $\begin{array}{l}\text { Personal, social and } \\
\text { moral development } \\
\text { through team games: } \\
\text { some critical questions. }\end{array}$ & $\begin{array}{l}\text { Little empirical evidence exists to support } \\
\text { team games being a vehicle for children's } \\
\text { personal, social and moral development in PE. } \\
\text { It is argued that clearer conceptual definitions } \\
\text { and critical debate within the PE profession } \\
\text { are needed in order to determine the role of } \\
\text { team games in promoting pupils' personal, } \\
\text { social and moral education. }\end{array}$ \\
\hline
\end{tabular}




\begin{tabular}{|c|c|c|}
\hline Publication & Title & Findings \\
\hline $\begin{array}{l}\text { Danish, S., Forneris, T., } \\
\text { Hodge, K., \& Heke, I. } \\
\text { (2004). World Leisure } \\
\text { Journal, 46(3), 38-49. }\end{array}$ & $\begin{array}{l}\text { Enhancing youth } \\
\text { development through } \\
\text { sport }\end{array}$ & $\begin{array}{l}\text { Sport is more than physical activity. To realise } \\
\text { these outcomes educators and coaches need } \\
\text { to: 1. develop skills in instructional design and } \\
\text { program development and evaluation; and } \\
\text { 2. must reach more adolescents with these } \\
\text { programs and encourage school-based and } \\
\text { after-school based programs to adopt Sport- } \\
\text { Based Life Skills Programs, such as - Teaching } \\
\text { Personal \& Social Responsibility through } \\
\text { Physical Activity (Hellison 1995); Sports United } \\
\text { to Promote Education and Recreation (Danish } \\
\text { 2002) and the Hokowhitu Program (Heke, } \\
\text { 2001). }\end{array}$ \\
\hline $\begin{array}{l}\text { Quay, J. \& Peters, } \\
\text { J. (2008). Journal of } \\
\text { Curriculum Studies, } \\
40(5), 601-626 .\end{array}$ & $\begin{array}{l}\text { Skills, strategies, sport, } \\
\text { and social responsibility: } \\
\text { reconnecting physical } \\
\text { education. }\end{array}$ & $\begin{array}{l}\text { Bringing together the five models of Teaching } \\
\text { Personal \& Social Responsibility through } \\
\text { Physical Activity, Creating and Developing } \\
\text { Games, SE in PE Program, Teaching } \\
\text { Games for Understanding and Fundamental } \\
\text { Movement Skills this program suggests a } \\
\text { connection can be made with children's lives } \\
\text { beyond the PE lesson. }\end{array}$ \\
\hline $\begin{array}{l}\text { Hellison, D. (2011). 3rd } \\
\text { Edition, Human Kinetics. }\end{array}$ & $\begin{array}{l}\text { Teaching personal and } \\
\text { social responsibility } \\
\text { through physical activity }\end{array}$ & $\begin{array}{l}\text { Introduce and provide an array of materials to } \\
\text { support the implementation of the Teaching } \\
\text { Personal and Social; Responsibility through } \\
\text { Physical Activity (TPSR) model as a proven } \\
\text { effective in school-based PE program. }\end{array}$ \\
\hline
\end{tabular}

An emerging field of discussion revealed in the literature scan was that of Physical Literacy. Lundvall (2015) provided a synthesis of the literature in the field of Physical Literacy since 2000. The potential for Physical Literacy to positively re-brand and revitalise PE was suggested, however, in some jurisdictions the concept had been misrepresented as a synonym for fundamental movement skill teaching or sport skill teaching. It is recognised that the concept of Physical Literacy is contested with questions raised about multiple definitions and empirical support for the assertions associated with the concept. We suggest the current debate about Physical Literacy is an extension of the ongoing challenge for PE to move beyond what Dyson, Griffin \& Hastie (2004) described as 'superficial engagement' with matters of pedagogy to move towards better informed practice that 'powers up' sport teaching in PE. Recently, Physical Literacy seems to have been re-imagined away from its origins as a philosophy (Whitehead, 2001) and a potential outcome of PE (Sprake and Walker, 2015) to a pedagogical proposition and model for PE in search of a supportive pedagogical argument and structure (Kirk, 2013).

\section{Conclusion}

The major findings of the comparative analysis were:

1. Game Based approaches (such as Game Sense (Australia)) to learning in PE technical and tactical dimensions of skilled performance in game play are promoted in preference to direct instruction or practice based models;

2. The SE curriculum and instruction model is well researched and validated as a design to provide authentic, educationally rich sport experiences for students in the context of school PE; and 
3. Personal and social development is an often-cited outcome of quality PE teaching in schools and to be achieved needs to be a deliberate pedagogical focus of the PE teacher.

The relevance of contemporary pedagogies through MBP based approaches like the gamebased model (such as the Australian Game Sense approach), SE and TPSR are encouraging innovation away from the more historically common directive practice style of the 'traditional' PE method. With respect to game-based models, the literature is challenging educators to use pedagogical approaches that have been shown to enhance learner engagement compared to a more traditional directive style framing sport as sport techniques when teaching for game competency. To fully deliver on the Arnoldian idea of PE as education in, through and about movement using sport as the educative vehicle, the SE model has been shown to be a curriculum model through which those three educative pillars can be enacted. Directly linking sport teaching and learning in PE through this Arnoldian concept, Sport Literacy (Drummond \& Pill, 2011; Pill, 2015) has been specifically described as a curriculum concept for the valuing of learning in, through and about sport in PE. Sport literacy is potentially both a praxis and curriculum scaffold for sport curriculum design and enactment in PE. 


\section{References}

Alexander, K., \& Penney, K. (2005). Teaching under the influence: feeding games for understanding into the sport education development-refinement cycle. Physical Education and Sport Pedagogy, 10(3), 287-301.

Arnold, P. (1979). Meaning in movement, sport and physical education. London: Heinemann.

Austin, B., Haynes, J., \& Miller. J. (2004). Using a game sense approach for improving fundamental movement skills. Paper Presented at the Australian Association for Research in Education Conference Melbourne, Victoria. December 2004.

Australian Council for Health, Physical Education and Recreation (ACHPER). (2008) Draft statement on a national curriculum and physical education - Information and feedback. Accessed 30.09.2010 at http://www.achper.org.au/new.php

Bailey, R., \& Kirk, D. (2009). Introduction. In R. Bailey \& D. Kirk (Eds.), The Routledge physical education reader. (pp. 1-6). New York, NY: Routledge.

Brock, S. J. \& Hastie, P.A. (2007). Students' conceptions of fair play in sport education. ACHPER Healthy Lifestyles Journal, 54(1), 11-15.

Brown, T., \& Penney, D. (2012). Learning 'in', 'through' and 'about' movement in senior physical education? The new Victorian certificate of education physical education. European Physical Education Review, online ahead of print, DOI: 10.1177/1356336X12465508

Browne, T., Carlson, T., \& Hastie, A. (2004). A comparison of rugby seasons presented in traditional and sport education formats. European Physical Education Review, 10(2), 199-214.

Brooker, R. \& Macdonald, D. (1993) Years of turbulence in Queensland Health and Physical Education: 1984-1991 (Part Two). The ACHPER National Journal, 40(1), 4-9.

Casey, A. (2014) Models-based practice: great white hope or white elephant? Physical Education and Sport Pedagogy, 19 (1), 18 - 34.

Chow, J. Y., Davids, K., Button, C., Shuttleworth, R., Renshaw, I. \& Araújo, D. (2007). The Role of Nonlinear Pedagogy in Physical Education. Review of Educational Research. 77(3), 251-278.

Danish, S. J. (2002). SUPER (sports united to promote education and recreation) program leader manual, $3^{\text {rd }}$ edn. Richmond, VA: Life Skills Center, Virginia Commonwealth University.

Danish, S., Forneris, T., Hodge, K., \& Heke, I. (2004). Enhancing youth development through sport. World Leisure Journal, 46(3), 38-49.

Drummond, M. \& Pill, S. (2011). The role of physical education in promoting sport participation in school and beyond. In S. Georgakis \& K. Russell (Eds.), Youth sport in Australia (pp. 171-184). Sydney, NSW: Sydney University Press.

Dyson, B., Griffin, L. L., \& Hastie P. (2004). Sport education, tactical games, and cooperative learning: Theoretical and pedagogical considerations. Quest, 56(2), 226-240.

Ennis, C. D. (1999) Creating a culturally relevant curriculum for disengaged girls. Sport, Education and Society, 4(1), 31-49.

Farrow, D. \& Reid, M. (2010). The effect of equipment scaling on the skill acquisition of beginning tennis players. Journal of Sports Sciences, 28(7), 723-732.

Gimenez, A.M., Valenzuela, A.V., \& Casey, A. (2010). What are we being told about how to teach games? A three-dimensional analysis of comparative research into different instructional studies in physical education and school sports. International Journal of Sport Science, 6(18), 37-56. 
Green, K. (2000). Exploring the everyday 'philosophies' of physical education teachers from a sociological perspective. Sport, Education and Society, 9(2), 109-129.

Harvey, S., \& Jarrett, K. (2013). A review of the game-centred approaches to teaching and coaching literature since 2006. Physical Education and Sport Pedagogy, 19(3), 278-300.

Harvey, S., Kirk, D., \& O'Donovan, T. M. (2014) Sport Education as a pedagogical application for ethical development in physical education and youth sport. Sport, Education and Society, 19(1), 41-62.

Hastie, P. (2005). Problem-solving in teaching sports. In Critical Inquiry and Problem Solving in Physical Education. Routledge.

Hastie, P., de Ojeda, D. M., Caldero'n Luquin, A. (2011). A review of research on sport education: 2004 to 2011. Physical Education and Sport Pedagogy, 6(2), 103-132.

Hastie, P.A., \& Buchanan, A. M. (2000) Teaching responsibility through sport education: prospects of a coalition. Research Quarterly for Exercise and Sport, 71(1), 25-35.

Hastie, P.A., \& Casey A. (2014) Fidelity in models-based practice research in sport pedagogy: A guide for future investigation. Journal of Teaching in Physical Education, 33, 422-431.

Hastie, P.A., Calderón, A., Rolim, R.J., \& Guarino, A.J. (2013). The development of skill and knowledge during a sport education season of track and field athletics. Research Quarterly for Exercise and Sport, 84(3), 336-344.

Heke, I. (2001). The Hokowhitu program: Designing a sporting intervention to address alcohol and substance abuse in adolescent Maori. Dunedin, NZ: Unpublished manuscript, University of Otago.

Hellison, D. (2011). Teaching personal and social responsibility through physical activity, 3rd Edition. Human Kinetics.

Hopper, T., \& Bell, R. (2001) Games classification system: Teaching strategic understanding and tactical awareness. CAHPERD, 66 (4), 14-19.

Kirk D. (1988). Physical education and curriculum study: A critical introduction. London: Croom Held.

Kirk, D. (2004) Framing quality physical education: the elite sport model or sport education? Physical Education and Sport Pedagogy, 9(2), 185-195.

Kirk, D. (2006). Sport education, critical pedagogy, and learning theory: Toward an intrinsic justification for physical education and youth sport. Quest, 58, 255-264.

Kirk, D. (2010). Physical education futures. New York, NY: Routledge.

Kirk, D. (2013). Educational value and models-based practice in physical education. Educational Philosophy and Theory 45(9): 973-986. DOI: 10.1080/00131857.2013.785352.

Laker, A. (2002). Culture, education and sport. In A. Laker (Ed.), The sociology of sport and physical education: An introductory reader (pp. 1-14). London: RouledgeFalmer.

Laker, A. (2003). The future of physical education: Is this the 'new pedagogy'? In A. Laker (Ed.), The future of physical education: Building a new pedagogy (pp.153-170). London: Routledge.

Light, R. (2013). Game Sense Pedagogy. In Game Sense: pedagogy for performance, participation and enjoyment. Routledge.

Light, R. (2013). The development of Game sense. In Game Sense: pedagogy for performance, participation and enjoyment. Routledge.

Light, R. (2014). Positive pedagogy for physical education and sport: Game Sense as an example. In Contemporary developments in game teaching. Routledge. 
Light, R. L. \& Harvey, S. (2015). Positive Pedagogy for sport coaching. Sport, Education and Society, Published online 04 Mar 2015.

Light, R., Curry, C., \& Mooney, A. (2014). Game Sense as a model for delivering quality teaching in physical education. Asia-Pacific Journal of Health, Sport and Physical Education, 5(1), 67-81.

Lopez, G., Jordan, L., Penney, D., \& Chandler, T. (2009). The role of transfer in games teaching: Implications for the development of the curriculum. European Physical Education Review, 15 (1), 47-63.

Lundvall, S. (2015). Physical literacy in the field of physical education - a challenge and a possibility. Journal of Sport and Health Science, 4, 113-118

Mandigo, J. L., \& Holt, N.L. (2000). The inclusion of optimal challenge in teaching games for understanding. Physical and Health Education Journal, 66(3), 14-19.

Metzler, M. (2011). Instructional models for teaching physical education. Scottsdale, AZ: Holocomb Hathway.

Ministerial Council on Education, Employment, Training and Youth Affairs. (2008). Melbourne declaration on educational goals for young Australians. Melbourne: Curriculum Corporation.

Mitchell, S., Oslin, J., \& Griffin, L. (2013). Teaching sport concepts and skills, $3^{\text {rd }}$ Edn. Champaign, III: Human Kinetics.

Mohr, D. J., Townsend, J. S \& Pritchard, T. (2006). Rethinking middle school physical education: Combining lifetime leisure activities and sport education to encourage physical activity. The Physical Educator, 18-29.

Mosston, M. (1966). Teaching physical education: From command to discovery. Columbus, OH: Charles E. Merrill Books.

Moston, M., \& Ashworth, S. (2008). Teaching physical education- first online edition. San Francisco, CA: Pearson Education.

Parker, M. B. \& Matthew Curtner-Smith, M. (2005). Health-related fitness in sport education and multiactivity teaching. Physical Education and Sport Pedagogy, 10(1), 1-18.

Perlman, D. (2012). The influence of the sport education model on amotivated students' in-class physical activity. European Physical Education Review, 18(3) 335-345.

Pill, S. (2008). Sport literacy: it's not just about learning to play sport via 'textbook techniques'. Journal of Student Wellbeing, 4(2), 32-42

Pill, S. (2011) Seizing the moment: Can game sense further inform sport teaching in Australian physical education. PHENex Journal, 3(1).

Pill, S. (2015). Valuing learning in, through and about sport-physical education and the development of sport literacy. In H. Askell-Williams (Ed.), Transforming the Future of Learning with Educational Research (pp. 2-35). IGI Global.

Prout A. \& Hallett, C. (2003). Hearing the voices of children: social policy for a new century. New York, NY: Routledge Falmer.

Quay, J. \& Peters, J. (2008). Skills, strategies, sport, and social responsibility: reconnecting physical education. Journal of Curriculum Studies, 40(5), 601-626.

Richard, J.-F., Godbout, P., \& Grèhaigne, J.-F. (2000) Students' precision and interobserver reliability of performance assessment in team sports. Research Quarterly for Exercise and Sport, 71(1), 85-91.

Roberts, S., \& Fairclough, S. (2012). A five-stage process for the development and validation of a systematic observation instrument: The system for observing the teaching of games in physical education (SOTG-PE). European Physical Education Review 18(1) 97-113. 
Rui Araújo, R., Mesquita, I. \& Hastie, P. A. (2014). Review of the status of learning in research on sport education: Future research and practice. Journal of Sports Science and Medicine, 13, 846-858.

Siedentop, D., Hastie, P., \& van der Mars, H. (2011). Complete guide to sport education. Champaign, III: Human Kinetics.

Sprake, A. \& Walker, S. (2015) 'Blurred lines': The duty of physical education to establish a unified rationale. European Physical Education Review 21(3): 394-406.

Stolz, S. \& Pill, S. (2014). Teaching games and sport for understanding: Exploring and reconsidering its relevance in physical education. European Physical Education Review, 20(1), 36-71.

Teaching Games for Understanding (TGfU) Special Interest Group (2016). TGfU Home. Accessed 30.04.2016 at http://tgfuinfo.weebly.com/

Theodoulides, A. \& Armour, K.M. (2001). Personal, social and moral development through team games: some critical questions. European Physical Education Review, (1), 5-23.

Tinning, R. (2008). Pedagogy, sport pedagogy, and the field of kinesiology. Quest, 60(3), 405-424.

Wallhead, T. \& O'Sullivan, M. (2005). Sport Education: physical education for the new millennium? Physical Education and Sport Pedagogy, 10(2), 181-210.

Whitehead M (2001). The concept of physical literacy. European Journal of Physical Education 6(2): 127-138. 